\title{
Comparison of histometric and morphometric analyses of bone height in ligature-induced periodontitis in rats
}

\author{
Análise comparativa da altura óssea \\ histométrica e morfométrica na periodontite \\ induzida por ligadura em ratos
}

\section{Marilene Issa Fernandes ${ }^{(\mathbf{b})}$ Eduardo José Gaio(a) Rui Vicente Oppermann (b) Pantelis Varvaki Rados ${ }^{(b)}$ Cassiano Kuchenbecker Rosing ${ }^{(b)}$}

(a) Graduate Student; (b) Professors, Graduate Program in Dentistry - School of Dentistry, Federal University of Rio Grande do Sul.

\begin{abstract}
The purpose of this study was to compare histologic and morphometric procedures of bone height measurement. Microscopic measurements are the most frequent methods in periodontal studies with animals, but have limited capacity to identify bone levels associated with both healthy tissues and periodontal disease. Ligatures were placed in the maxillary left second molars of 10 male 60-day-old Wistar rats for 30 days. Left and right maxillary sides of 5 rats were processed for histologic analysis $(\mathrm{H})$, sectioned buccolingually, and stained with HE. The maxillae of the other 5 rats were defleshed and used for morphometric analysis $(\mathrm{M})$. Histometric measurements from the cementoenamel junction to the bone crest were performed. Standardized photographs were used for morphometric analysis. The $t$ test was used for dependent or independent samples $(\alpha=0.05 \%)$. Distances from cementoenamel junction to bone crest were $0.95 \pm 0.25$ and $1.07 \pm 0.30 \mathrm{~mm}$ for $\mathrm{H}$ and $\mathrm{M}$, respectively. Buccal measurements were $0.92 \pm 0.16$ and $1.08 \pm 0.35 \mathrm{~mm}$ for $\mathrm{H}$ and $\mathrm{M}$. The values obtained using $\mathrm{H}$ and $\mathrm{M}$ for areas without ligatures were $0.44 \pm 0.15$ and $0.47 \pm 0.11 \mathrm{~mm}$ for lingual measurements and $0.23 \pm 0.08$ and $0.41 \pm 0.10 \mathrm{~mm}$ for buccal measurements. No significant differences were found between the two methods in the detection of bone height associated with the placement of ligatures in rats.
\end{abstract}

Descriptors: Histology; Alveolar bone loss; Periodontium.

Resumo: O objetivo deste estudo foi comparar procedimentos de medida da altura óssea histológica e morfométrica. O método mais freqüente de mensuração da altura óssea em estudos em animais são as medidas microscópicas. No entanto, tem limitada capacidade de identificar os níveis ósseos associados com os tecidos saudáveis e doença periodontal. Foram colocadas ligaduras no segundo molar superior esquerdo de 10 ratos machos Wistar com 60 dias de vida durante um período de 30 dias. Hemimaxilas direitas e esquerdas de 5 ratos foram processadas para a análise histológica $(\mathrm{H})$, cortadas no sentido vestíbulo-lingual e coradas com HE. Hemimaxilas dos outros 5 ratos tiveram toda a matéria orgânica removida para análise morfométrica (M). Medidas histométricas da junção cemento-esmalte (JCE) à crista óssea alveolar foram realizadas. Fotografias padronizadas foram utilizadas na análise morfométrica. O teste $t$ foi utilizado para amostras dependentes e independentes $(\alpha=0,05 \%)$. As distâncias entre a JCE e a crista óssea na face palatina foram de $0,95 \pm 0,25$ e $1,07 \pm 0,30 \mathrm{~mm}$ para $\mathrm{H}$ e $\mathrm{M}$, respectivamente. As medidas vestibulares foram $0,92 \pm 0,16$ e $1,08 \pm 0,35 \mathrm{~mm}$ para $\mathrm{H}$ e M. Os valores obtidos usando $\mathrm{He}$ M para áreas sem ligadura foram $0,44 \pm 0,15$ e $0,47 \pm 0,11 \mathrm{~mm}$ por lingual e 0,23 $\pm 0,08$ e 0,41 $\pm 0,10 \mathrm{~mm}$ por vestibular, respectivamente. Não houve diferenças estatisticamente significativas entre os dois métodos na detecção da altura óssea associada à colocação de ligaduras em ratos.

Descritores: Histologia; Perda óssea alveolar; Periodonto.
Received for publication on Jun 23, 2006 Sent for alterations on Aug 18, 2006 Accepted for publication on Sep 18, 2006 


\section{Introduction}

Rats have been used in periodontal disease studies ${ }^{4,9,10,12,14}$ because their periodontal tissue structure in the molar region is similar to that of human beings. ${ }^{20}$ Moreover, rats can be kept in germfree conditions $s^{1,5}$ and have their immunologic capacity compromised, ${ }^{11}$ which makes them an attractive model for better understanding the pathogenesis of periodontal diseases.

Several methods have been used to evaluate periodontal bone loss in rats. Studies have described lesions macroscopically, ${ }^{15,28}$ histologically ${ }^{3,17,18}$ or radiographically. ${ }^{2,10,15}$ The histologic method is currently the criterion standard, but it has drawbacks, especially because the pattern of bone resorption in periodontitis is not uniform..$^{14,24}$ In addition, problems during histologic processing, difficulties in carrying it out, its high cost and long time requirements are well-known disadvantages of histologic analyses. However, histologic sections can be used not only for the investigation of alveolar bone loss, but also for other studies, such as loss of attachment, ${ }^{6}$ inflammatory infiltrate, ${ }^{7}$ tissue characteristics such as collagen type,$^{23}$ and immunohistochemical analyses. $^{25}$

Differences in bone resorption may be important for the evaluation of the methods under investigation in this study. As bone loss is one of the outcomes of periodontal disease, the development of an alternative method to determine the exact anatomy of bone defects is necessary. Therefore, this study compared the measurement of bone height in healthy and diseased periodontal tissue using histologic sections and morphologic analysis of dry bone.

\section{Material and Methods Animal model}

Ten male 60-day-old Wistar rats weighing 250 to 350 grams were used. The rats were kept in plastic cages and received food (Nuvilab ${ }^{\circledR}$, Curtiba, PR, Brazil) and water ad libitum. The animals were kept in a gnotobiotic environment in the Biomedical Sciences Institute, Federal University of Rio Grande do Sul. This study was approved by the Ethics Committee, School of Dentistry, Federal University of Rio Grande do Sul, RS, Brazil.

\section{Experiment}

For the placement of ligatures (3-0 cotton suture - Ethicon, Johnson \& Johnson ${ }^{\circledR}$, São Paulo, SP, Brazil) to induce bone loss, the animals were anesthetized with IM administration of ketamine hydrochloride (Dopalen ${ }^{\circledR}$, Agribrands Brasil Ltda., Paulínea, SP, Brazil) and xylazine hydrochloride (Rompun ${ }^{\circledR}$, Bayer S.A., São Paulo, SP, Brazil). Ligatures were placed in the maxillary left second molar (test side) and were kept for 30 days. Contralateral teeth, without ligatures, were used as controls. The rats were euthanized by cervical dislocation. The maxillae were removed and sectioned medially.

\section{Specimen preparation and histologic analysis}

Ten maxillary sides (test and control sides) were fixed in $10 \%$ buffered formalin (Sigma-Aldrich ${ }^{\circledR}$, Saint Louis, MO, USA) for 48 hours. The specimens were kept in Anna Morse solution for 40 days (20\% sodium citrate and $50 \%$ formic acid) for decalcification. The decalcified specimens were individually neutralized in sodium bicarbonate and prepared for histologic analysis. The specimens were embedded, and three $3-\mu \mathrm{m}$ buccolingual sections (E. Leitz ${ }^{\circledR}$, Wetzlar, Hesse, Germany) from the maxillary second molar area ${ }^{8}$ were obtained from each specimen. The sections were stained with $\mathrm{HE}^{13}$ (Pró-Cito ${ }^{\circledR}$, Porto Alegre, RS, Brazil).

The criterion for inclusion of slides was the presence of a portion of the root, epithelial tissue and bone crest in the same section. Images of these sections were captured by a 4-megapixel digital camera (Nikon ${ }^{\circledR}$ Coolpyx, Ayutthaya, Ayutthaya, Thailand) at $50 \mathrm{X}$ magnification. A calibrating microscopic scale (E. Leitz ${ }^{\circledR}$, Wetzlar, Hesse, Germany) was photographed together with the section to be used for conversion of the measurement results. A trained observer, blinded to the group to which the slide belonged, used the ImageTool ${ }^{\circledR} 3.0$ software (UTHSCSA, San Antonio, TX, USA) to obtain 3 linear measurements from bone crest to cementoenamel junction (CEJ) at the buccal and palatal root of the second upper molar. The longest measure was selected for analysis of the results (Figure 1). 


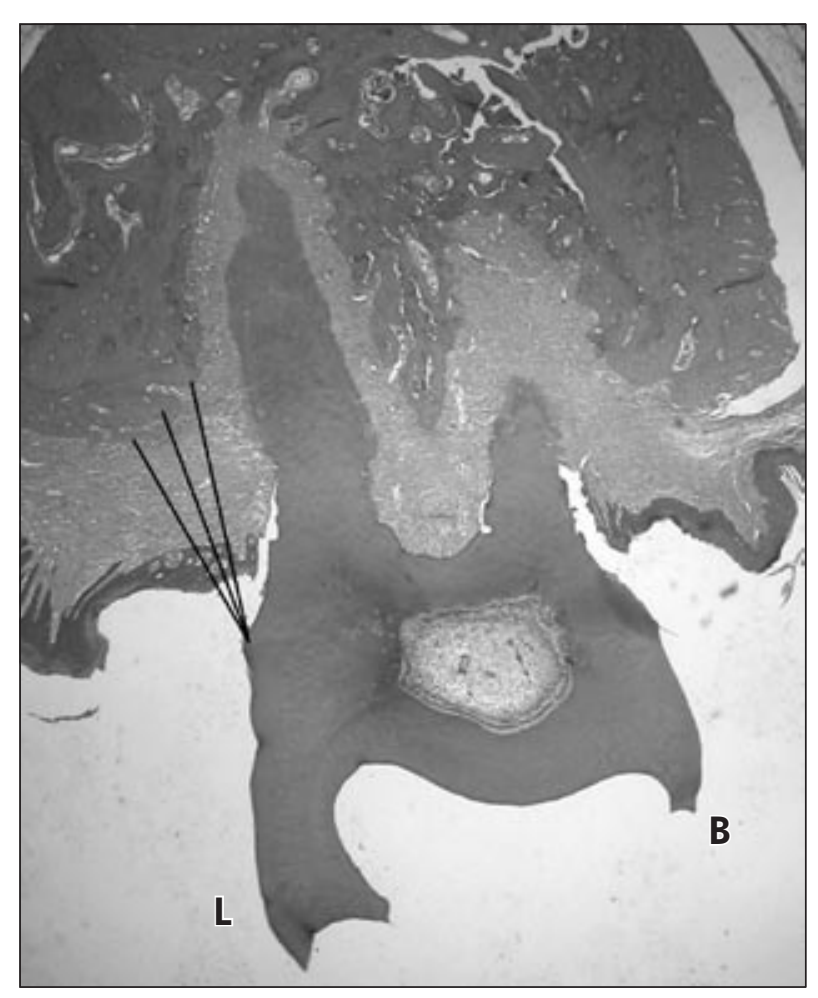

Figure 1 - Histologic analysis: linear measurement from bone crest to cementoenamel junction. B: buccal side; L: lingual side.

\section{Specimen preparation and morphologic analysis}

Ten maxillary sides (test and control sides) were defleshed after immersion in $8 \%$ sodium hypochlorite (Q'boa ${ }^{\circledR}$, Osasco, SP, Brazil) for 4 hours. The specimens were washed in running water and immediately dried with compressed air. To outline the CEJ, $1 \%$ methylene blue (Sigma-Aldrich ${ }^{\circledR}$, Saint Louis, MO, USA) was applied to the specimens for 1 minute. Photographs were obtained with a 6.1megapixel digital camera (Nikon ${ }^{\circledR}$ D100, Ayutthaya, Ayutthaya, Thailand) on a tripod to keep the camera parallel to the ground at the minimal focal distance. The specimens were fixed in wax and kept with their occlusal plane parallel to the ground and their long axis perpendicular to the camera. Photographs of the buccal and lingual aspects were made. To validate measurement conversions, a millimeter ruler was photographed together with all specimens. The ImageTool ${ }^{\circledR}$ software was used by an observer blinded to the group to which the slide belonged to obtain

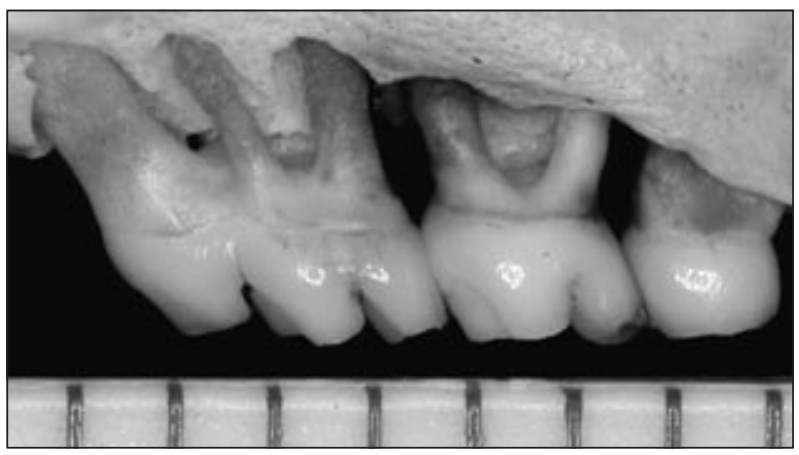

Figure 2 - Morphometric analysis: linear measurement from bone crest to cementoenamel junction.

3 linear measurements from the bone crest to the cementoenamel junction (CEJ). The longest measure was selected for analysis of the results (Figure 2).

\section{Statistical analysis}

Mean ( \pm standard deviation) distances from the CEJ to the bone crest were obtained for the test and control sides of the maxillae analyzed by both the histologic and morphometric methods. For intragroup morphometric or histologic analysis, the measures of the ligature sides and the sides without ligatures were compared with the $t$ test for paired samples. For the analysis between groups, comparing morphometry with histology, the test and control sides were compared with the $t$ test for independent samples. Significance level was established at $\alpha=0.05$.

\section{Results}

The results are shown in Table 1 and Graph 1. In all the buccal and lingual areas evaluated by the histometric and morphometric analyses, the ligatures generated a greater alveolar bone loss, and the differences were statistically significant $(t$ test for paired samples; $\mathrm{p}<0.05$ ).

Table 1 compares the histometric and morphometric methods. The lingual areas of the teeth with or without ligature and the buccal areas of the teeth with ligatures showed no significant differences between methods ( $t$ test for paired samples; $\mathrm{p}>0.05$ ). However, a mean value ( \pm standard deviation) of $0.23( \pm 0.08) \mathrm{mm}$ for the buccal area of the teeth without ligature was found in the histometric analy- 
Table 1 - Evaluation of induced bone loss: comparison between histologic and morphologic methods for obtaining linear measurements $(\mathrm{mm})$ from bone crest to CEJ, for buccal and lingual sides with and without ligatures.

\begin{tabular}{l|c|c|c|c}
\hline & Buccal with ligature & Lingual with ligature & Buccal without ligature & Lingual without ligature \\
\hline Histometry & $0.92 \pm 0.16$ & $0.95 \pm 0.25$ & $0.23 \pm 0.08^{*}$ & $0.44 \pm 0.15$ \\
\hline Morphometry & $1.08 \pm 0.35$ & $1.07 \pm 0.30$ & $0.41 \pm 0.10^{*}$ & $0.47 \pm 0.11$ \\
\hline
\end{tabular}

*Statistically significant difference between Histometry and Morphometry (t test for independent samples).

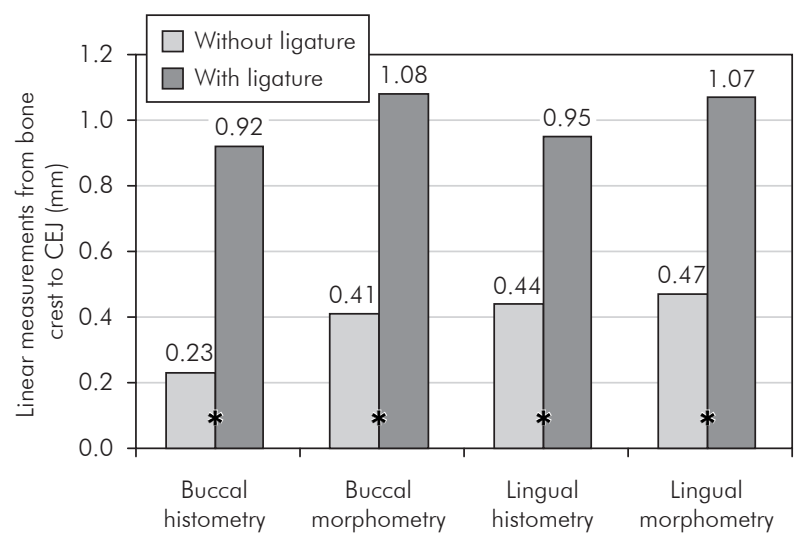

Graph 1 - Evaluation of induced bone loss: comparison between histologic and morphologic methods for buccal and lingual sides with and without ligatures. *Statistically significant different mean values between teeth with and without ligatures - paired sample $t$ test.

sis. This result was statistically different from the mean obtained for corresponding areas when the morphometric method was used $(0.41 \pm 0.10 \mathrm{~mm})$.

\section{Discussion}

This study compared two methods - histometry and morphometry - to evaluate ligature-induced alveolar bone loss in Wistar rats. As different forms of bone loss evaluation have been reported in literature, the purpose of this study was to develop a reliable study method.

Histologic evaluation is the standard method used in most studies. Susin, Rösing ${ }^{26}$ (2003) used Wistar rats and evaluated bone height histologically in a linear procedure; they used the interproximal space of first and second molars and measured the distance from the CEJ up to the apical-most point of the bone crest. Nociti et al. ${ }^{18}$ (2000) and Nogueira-Filho et al. ${ }^{19}$ (2004) used histology to measure bone loss area $\left(\mathrm{mm}^{2}\right)$ in the first molar furcation of Wistar rats.
Other forms of bone loss evaluation have been used recently. Rivaldo et al. ${ }^{21}$ (2005) used defleshed mandibles of Mus domesticus rats to evaluate changes in bone height and measured bone loss as the exposed root surface area $\left(\mathrm{mm}^{2}\right)$ in first and second molars. Bone loss was measured as follows: mesially, a line from the CEJ to the bone crest in the mesial root of the first molar, and distally, a line for the CEJ to the bone crest in the distal root of the second molar; coronally, from the bone crest to the apical-most portion of the CEJ, and apically, from the CEJ to the apical-most point of the bone crest. Kuhr et al. ${ }^{16}$ (2004) evaluated ligature-induced bone loss in defleshed mandibles of rats using two methods. In one method, the distance from the CEJ to the bone crest was measured linearly in different sites; in the other, the exposed root surface area was measured. Their study concluded that the method of measuring the linear distance should be preferred to the method of area evaluation.

The present study used 5 Wistar rats to evaluate induced bone loss and compare two methods: histologic evaluation, measuring bone loss linearly, ${ }^{26}$ and morphometric evaluation, measuring bone loss linearly in defleshed maxillae. ${ }^{16}$ The observer was previously trained to conduct the measurements and was blinded to which experimental group the images belonged. ${ }^{27}$ The study and control groups were used to compare the capacity of the induction method to generate alveolar bone loss and to compare maxillae in which bone loss was induced using two different methods of analysis.

The main purpose of this study was to compare the histometric and morphometric methods. Therefore, sections were buccolingual and not mesiodistal, differently from most studies. ${ }^{3,22}$ The morphometric analysis used digital photographs of the buccal and 
lingual aspects of the dry maxillae. The histometric analysis used histologic sections whose images were digitized for evaluation.

The results of this study showed that both methods are capable of detecting vertical periodontal bone loss in test and control teeth. The statistically significant differences found between teeth with and without ligatures in both methods demonstrated that the placement of ligatures generated bone loss, which validates the use of ligatures in this study. Moreover, bone loss generated by ligatures was found in both histometric and morphometric analyses (Graph 1).

The comparison between methods, however, revealed statistically significant differences between the groups without ligature when the buccal surface was analyzed. No differences between methods were found in the analysis of the other tooth surfaces (Table 1).

Future studies should investigate an explanation for this finding. However, the low values $($ mean $=0.23 \mathrm{~mm})$ found for the control group (without ligature) in the histometric analysis of the buccal surfaces were substantially lower than those reported for control groups in studies with rats in which the same distance was measured. Moreover, the mean value for the group without ligature in the morphometric analysis was $0.41 \mathrm{~mm}$, similar to the

\section{References}

1. Amstad-Jossi M, Schroeder HE. Age-related alterations of periodontal structures around the cemento-enamel junction and of the gingival connective tissue composition in germ-free rats. J Periodontal Res. 1978;13(1):76-90.

2. Bjornsson MJ, Velschow S, Stoltze K, Havemose-Poulsen A, Schou S, Holmstrup P. The influence of diet consistence, drinking water and bedding on periodontal disease in SpragueDawley rats. J Periodontal Res. 2003;38(6):543-50.

3. Breivik T, Thrane PS, Gjermo P, Fonnum F. Postnatal glutamate-induced central nervous system lesions alter periodontal disease susceptibility in adult Wistar rats. J Clin Periodontol. 2001;28(10):904-9.

4. Chang KM, Ramamurthy NS, McNamara TF, Genco RJ, Golub LM. Infection with a gram-negative organism stimulates gingival collagenase production in non-diabetic and diabetic germfree rats. J Periodontal Res. 1988;23(4):239-44.

5. Crawford JM, Taubman MA, Smith DJ. The natural history of periodontal bone loss in germfree and gnotobiotic rats in- values obtained in the histometric and morphometric analyses of the lingual areas. This finding was discrepant with findings for the other groups in this study, and might have been caused by an unwanted inclination of the histologic sections. Despite the care taken, such inclination may have generated an occlusal image of the alveolar bone crest. This is one of the problems of histometry, particularly when maxillae, for which parallel positioning may be difficult to obtain, are the object of investigation. The concomitant use of morphometric analysis may mitigate such effect. However, this objective limitation of histometric measurements of ligature-induced alveolar bone loss in rats should not preclude its use. Other positive characteristics of histologic analysis should be explored, such as the possibility of identifying cell elements and components of soft tissue.

This study contributed to the understanding that the use of morphometric analysis may be an alternative to histometric evaluations because it is faster, easier and less expensive, particularly when the only purpose of the study is to measure bone loss.

\section{Conclusion}

Both histometric and morphometric analyses are capable of detecting ligature-induced differences in bone height in rats.

fected with periodontopathic microorganisms. J Periodontal Res. 1978;13(4):316-25.

6. Dayan S, Stashenko P, Niederman R, Kupper TS. Oral epithelial overexpression of IL-1alpha causes periodontal disease. J Dent Res. 2004;83(10):786-90.

7. Dumitrescu AL, Abd-El-Aleem S, Morales-Aza B, Donaldson LF. A model of periodontitis in the rat: effect of lipopolysaccharide on bone resorption, osteoclast activity, and local peptidergic innervation. J Clin Periodontol. 2004;31(8):596603.

8. Fernandes MI, Gaio EJ, Rösing CK, Oppermann RY, Rados PV. Avaliação qualitativa microscópica do tempo de fixação e meio de descalcificação do periodonto em maxila de ratos. Braz Oral Res. 2003;17(Suppl 2):206.

9. Fitzgerald RJ, Jordan HV, Stanley HR. Experimental caries and gingival pathologic changes in the gnotobiotic rat. J Dent Res. 1960;39:923-35. 
10. Heijl L, Wennström J, Lindhe J, Socransky SS. Periodontal disease in gnotobiotic rats. J Periodontal Res. 1980;15(4):40519.

11. Holzhausen M, Garcia DF, Pepato MT, Marcantonio E Jr. The influence of short-term diabetes mellitus and insulin therapy on alveolar bone loss in rats. J Periodontal Res. 2004;39(3):188-93.

12. Jordan HV, Keyes PH, Bellack S. Periodontal lesions in hamsters and gnotobiotic rats infected with Actinomyces of human origin. J Periodontal Res. 1972;7(1):21-8.

13. Junqueira LCU, Junqueira LMMS. Técnicas básicas de citologia e histologia. São Paulo: Santos; 1983.

14. Klausen B, Evans RT, Sfintescu C. Two complementary methods of assessing periodontal bone level in rats. Scand J Dent Res. 1989;97(6):494-9.

15. Klausen B, Hougen HP, Eriksen WH, Fiehn NE. Introduction of periodontal bone loss in athymic (nude) rats monoinfected with Streptococcus mutans. J Periodontal Res. 1986;21(1):512.

16. Kuhr A, Popa-Wagner A, Schmoll H, Schwahn C, Kocher T. Observations on experimental marginal periodontitis in rats. J Periodontol Res. 2004;39(2):101-6.

17. Nishikawa S, Nagata T, Morisaki I, Oka T, Ishida H. Pathogenesis of drug-induced gingival overgrowth. A review of studies in the rat model. J Periodontol. 1996;67(5):463-71.

18. Nociti FH Jr, Nogueira-Filho GR, Primo MT, Machado MA, Tramontina VA, Barros SP et al. The influence of nicotine on the bone loss rate in ligature-induced periodontitis. A histometric study in rats. J Periodontol. 2000;71(9):1460-4.

19. Nogueira-Filho GR, Froes Neto EB, Casati MZ, Reis SR, Tunes RS, Tunes UR et al. Nicotine effects on alveolar bone changes induced by occlusal trauma: A histometric study in rats. J Periodontol. 2004;75(3):348-52.

20. Page RC, Schroeder HE. Periodontitis in man and other animals. A comparative review. Basel: Karger; 1982.

21. Rivaldo EG, Padilha DP, Hugo FN. Alveolar bone loss and aging: a model for the study in mice. J Periodontol 2005;76(11):1966-71.

22. Rovin S, Costich ER, Gordon HA. The influence of bacteria and irritation in the initiation of periodontal disease in germfree and conventional rats. J Periodontal Res. 1966;1(3):193204.

23. Sato Y, Kikuchi M, Ohata N, Tamura M, Kuboki Y. Enhanced cementum formation in experimentally induced cementum defects of the root surface with the application of recombinant basic fibroblast growth factor in collagen gel in vivo. J Periodontol. 2004;75(2):243-8.

24. Schmidt LJ, Rowe DJ. The effects of diphosphonates on alveolar bone loss. Quintessence Int. 1987;18(7):497-501.

25. Sculean A, Berakdar M, Windisch P, Remberger K, Donos N, Brecx M. Immunohistochemical investigation on the pattern of vimentin expression in regenerated and intact monkey and human periodontal ligament. Arch Oral Biol. 2003;48(1):7786.

26. Susin C, Rösing CK. Effect of variable moderate chronic stress on ligature-induced periodontal disease in Wistar rats. Acta Odontol Scand. 2003;61(5):273-7.

27. Susin C, Rösing CK. Praticando Odontologia Baseada em Evidências. Canoas: Ulbra; 1999.

28. Tatakis DN, Guglielmoni P. HLA-B27 transgenic rats are susceptible to accelerated alveolar bone loss. J Periodontol. 2000;71(9):1395-400. 